М.В.Лукашенко,

аспірантка Гуманітарного інституту

Наиіонального авіаційного університету

\title{
ФОРМУВАННЯ СОЦАЛЬНОСТІ ЯК ОСОБЛИВОГО ВИМІРУ ЛЮДСЬКОГО БУТТЯ В МОДЕРНИЙ ЧАС
}

Феномен соціальності став об' єктом вивчення філософів за доби модерну, коли відкриття Нового світу, дослідження нових меж зробили традиційну спільнотність затісною для західного світу. В умовах зруйнованих традиційних зв'язків виникає потреба в раціональному формуванні нових. Відбувалося те, що Ж. Липовецькі назвав секулярною сакралізацією нової ери в ім'я народу, рівності, нації, «нової людини», коли діє принцип «все або нічого» $[10,136]$. Питанням зіставлення нового і старого досвіду в різних соціальнофілософських контекстах надавали уваги Ф.Тьонніс, Г.Зіммель, М.Вебер, Ф.Ніцше, В.Беньямін, Б. Андерсон, Т.Парсонс, Р.Каюа, Ж. Липовецькі, Ч. Тейлор, Б. Латур, Ю.Габермас, З.Бауман.

Визначальною характеристикою модерну є новизна, перетворення традиційних суспільств, світогляду під впливом ідей Просвітництва. За словами Бернгарда Шеферса, цей процес відбувається «під приматом розуму, автономії і свободи, демократії і прав людини, а також на основі раціональності і соціального планування» [4].

Ознакою завершення новочасності є нівелювання протиставлення нового і старого, зменшення сугестивного ефекту новизни, інше сприйняття буття та часу. В модерному сприйнятті час швидкоплинний і прогресивно-лінійно спрямований у майбутнє. Як прокоментував це Ф. Ніцше, новочасні люди, вважаючи, що назавжди розірвали з минулим, прагнуть все датувати, зберігати і тому несуть хворобу історії в самих собі. За словами Б. Латура, «маніакальне руйнування симетричним чином компенсується таким самим маніакальним зберіганням» $[9,137]$. Новочасне відчуття знищення часу саме по собі пов'язується не так зі століттями, як із великою кількістю переворотів (коперниканський, кантівський, епістемілогічний, лінгвістичний та ін.). Проте новочасне людство не настільки віддалено від свого минулого, як вважають. Минуле залишається, а то й повертається, що викликає страх занурення в темні часи або в романтичне середньовіччя. 
Модерна соціальність розвивалась у сучасному (теперішньому) часі, який, на відміну від «одночасного», «месіанського» домодерного часу, $є$ «однорідним порожнім» (В. Беньямін). До новочасності неможливо було визначити час без маркерів соціального простору. Як каже Е.Гідденс, «коли» завжди було пов'язано з «де» або визначалось через природні явища, які повторювалися. Але поява механічного годинника, який став уособленням «чистого» часу, відокремила час від простору [6, 130-131]. Соціальність, що інтегрує соціальний організм, перехресно структурує однорідний порожній та історичний час. Новочасний соціальний організм переміщується, відповідно до календаря, в однорідному часі, що створює образ цілісності, яка рухається крізь історію [17].

На думку Б.Латура, люди змішують різні часи і знову стали доновочасними. Вони не рухалися вперед і не відступали, а відбирали елементи, які належать різним епохам. У підсумку це створює час, а не час породжує відбір [9, 144-145]. 3 огляду на сказане автор висловлює, на перший погляд, досить епатажну думку про те, що Нового часу не було, розглядаючи суспільство як модерний феномен у параметрах акторно-мережевої теорії, пропонуючи варіанти «перезборки» соціального, рухаючись від розуміння суспільства до колективів, в поняття яких вкладає особливий зміст. Мовляв, це такий феномен природ-культур, які не є суспільством як людиміж-собою і не $\epsilon$ природою як річчю-в-собі. Колективи поділяють на те, що у майбутньому стане елементами природи, а що -елементами соціального світу, тобто природа і суспільство є їх сателітами [9, 181-182]. Вони відрізняються розмірами - більша кількість об'єктів потребує більшої кількості суб'єктів, більший ступінь суб'єктивності вимагає більшого ступеня об'єктивності, а це відрізняє новочасові суспільства від доновочасових.

Ф. Тьонніс описав відмінності між спільнотою і суспільством, подавши їх у вигляді дихотомічних понять: «сутнісна і виборча воля», «самість і особа», «володіння і майно», «земля і гроші», «сімейне і зобов'язувальне право» $[15,185]$. В рамках даної роботи спільнотність розуміється як базові стосунки, інстинктивно-чуттєві органічні соціальні відносини, обумовлені спільним минулим, спільною долею, контакти мають властивість прямого доступу, з інтенцією до взаємозлиття. Суспільність, як модерне новоутворення, відображає усвідомлену залученість особи у сутнісно необхідну, цінніснораціональну мережу соціальних зв'язків, які $є$ полем людського 
буття. А саме суспільство постає як суб'єкт історичного та політичного процесів, як автономний, суверенний вимір людського буття, що має специфічні закономірності розвитку і впорядкування, котрі вийшли з меж ранньомодерних протиставлень індивіда і держави, громадянського суспільства і держави. Концептуальним виміром суспільності $є$ підкреслення значення соціальної природи людини, як похідної від суспільства $[5,9]$. Поняття соціальності також є модерним поняттям і означає зумовлені суспільством властивості соціальних зав'язків, що їх стягує на собі особистість, сповнюючи їх індивідуальним досвідом у певному культурно-історичному контексті.

Але чітко розділити спільнотність і суспільність за типами груп і зв'язків неможливо - спільнотність може реалізовуватися і в професійних, політичних групах, асоціаціях, які є ознаками суспільності. У тотальній західній новочасній динаміці набуття суспільності залишалися островки спільнотності (немобільні групи зі щільними зв'язками, коріннями), а в період реакційного повернення до традиціоналізму, про який говорив Р.Генон, відбувається залучення новітніх спільнот, створених за зразком минулого, в сучасне суспільство. В Україні XIX ст. ідея суспільності розвивається в просторі українофільства, починаючи від ідеї народності (соціальної автономії простолюду) і втілювалась у діяльності братств, політичних організацій, які фундаментально розмежовували суспільство і державну владу, наголошували на автономії особистості. В українському модерному суспільно-політичному дискурсі ідея суспільності займала чільне місце. Згідно з нею, суспільство розглядали як автономний суверенний вимір буття людини, як суб'єкт історичного процесу, а спільноту українців - як тих, хто має стати політичним сувереном [5, 6-8]

Початок модерного формування соціальності був пов'язаний iз проблемою інтеграції так званих небезпечних класів, які були тимчасово вилученими, «надлишком» населення $[2,105]$. Трагічний приклад «зайвих» людей становить ситуація у Великобританії та деяких інших Європейських країнах раннього Нового часу, яка увійшла в історію, як відгороджування. Образом іï були «вівці, які з’їли людей». Стрімке індустріально-економічне зростання і далі робило велику кількість людей «непотрібними» 3 професійного погляду. Водночас відбувалося руйнування самих традиційних соціальних зв'язків. Пошук та створення для небезпечних класів нових місць у модерній соціальній структурі - виклик новочасності. Звідси постає 
питання: як перейти від війни «всіх проти всіх» до нової форми солідарності, від дикого капіталізму до регульованої економіки, в якій буде місце для зреінтегрованого населення?

Модерне суспільство мобілізовувало маси на основі історичних задумів, інспіруючи своїх адептів науково-технічним оптимізмом, сподіванням на майбутнє і вірою в прогрес. Ідея свободи, яка виникла в суспільстві, перетворюється на стан, необхідний для соціальної інтеграції і самоорганізації соціальної системи [3]. Все це стало ідеальною основою соціальності, яка базувалась на своїй матеріальній основі - індустріальному виробництві - професійному залученні у великі системи. Взаємозв'язок і взаємовплив між ними відбувався в третьому вимірі соціальності - в сфері мас-медіа, масової комунікації.

Створювалась така соціальна реальність, яка з феноменологічної точки зору є «Ми-світом» і яка розглядається в інтерсуб'єктивному, спільнотному і суспільному аспектах життєсвіту [18]. 3 пошуком нової інтерсуб'єктивної єдності, необхідної людям, які втратили традиційну спільнотність, пов'язане виникнення такого суто новочасного феномену, як нації, які, на думку Б.Андерсона, розвиваються за законами уявлених спільнот.

Під поняттям нації розуміють таку уявлену політичну спільноту, яку вважають генетично обмеженою і суверенною. Попри те, що неможливо знати більшість людей своєї національності, кожний має образ їх співпричетності, всі поділяють і забувають багато спільних історій, мають відчуття глибокого і солідарного братерства [1, 22-24]. Націоналістична уява має глибоку спорідненість 3 релігійною, адже надзвичайно близько підходить до питань сенсу життя і смерті. Частково вона $є$ одним із субститутів релігійного почуття, зруйнованого в період Просвітництва.

Якщо продовжити наведені міркування, то національні зв'язки постають як такі, що не є зв'язками, які описуються поняттям «соціальність». Піднесення національних почуттів і актуалізація національних рухів не $\epsilon$ соціальністю, але $є$ тими фальсифікуючими умовами, в яких вона формується.

Починаючи від ідеї спільної волі Ж.-Ж.Руссо, націю розглядають як ціле, що має примат над особистим. Це ще один модерний парадокс. Найвищою цінністю є людина, її життя і свобода. 3 іншого боку, батьківщина, як соціально-політичне тіло, підпорядковує собі громадян. Тобто модерна соціальність потребує вільної 
людини, в умовах, які виключають свободу. Ця ранньомодерна амбівалентна інтенціональність осмислювалась у період пізнього модерну екзистенціалістами, зокрема Ж.-П.Сартром, який узагальнив це як приреченість людини до свободи. Новочасна людина стає примушеною до самоствердження в умовах, які М.Кундера назвав нестерпною легкістю буття.

За часів Просвітництва відбувається секуляризація уявлень про істину. Новочасну істину починає шукати наукове співтовариство в математиці, фізиці, механіці, для чого була необхідна сцієнтистсько-консюмеристська свобода досліджень, якої не потребували маси. Проте наука в новоєвропейському часі набула такої значущості, що її цінності були екстрапольовані на все суспільство, а створені гібриди науки і суспільства продукували нові виміри свобод та несвобод. Навколо наукових відкриттів народжується «нова природа, нова теологія, нова соціабельність вченого, нове суспільство, яке віднині буде включати в себе вакуум, учених і лабораторію» $[9,152]$. Соціальність, як сукупність соціальних зв'язків, містить об'єкти, без яких зв'язки не працюють. Ці об'єкти (наприклад, мікроби, відкриті Пастером, насос Бойля), хоча й переміщені із соціального світу в трансцендентний, продовжують конструювати соціальне, лишаючись водночас соціальними і асоціальними.

Культурною домінантою модерну стає картезіанський сумнів, наукова скептичність, як свобода невір'я замість віри. Обмеження кола цінностей пріоритетом раціонально-інтелектуальних тягне за собою поступове вихолощення поняття свободи [12, 210-211]. В такому дискурсі зароджується картезіанський суб'єкт, який стає дражливим привидом, що дотепер переслідує, на думку Ж. Славой, західну академічну вченість $[13,7]$. А в модерному дискурсі, за 3.Бауманом, народжується концепт свобідного індивіда, який є не універсальним станом людства, а продуктом історії і суспільства, який виникає разом із конкретним типом суспільства. Тобто свобода існує лише в сфері соціальних відносин [3, 18-19]. Поява іiі концепту i поширення пов'язані не лише із новочасністю, а й із капіталізмом.

Розвивається економічний вимір свободи, з прагненням до нічим не обмеженої торгівлі й конкуренції. На думку людини, чиїм ім'ям називають епоху зрілого індустріального модерну (фордизмом), свобода - це можливість самому розпоряджатися своїм життям, право на таку тривалість праці, яка була достатньою для гідного рівня життя $[16,13]$. 
3 економічним аспектом контексту розвитку соціальності, носієм якої є індивід, приречений на свободу і відповідальність, пов'язана ситуація тотального відчуження, як несправжнього способу існування, що робить людину «одновимірною» (Г.Маркузе). В окресленому контексті в період завершення новочасної ери індустріального суспільства формуються дві основні позиції аналізу феномену свободи екзистенціалізм і біхевіоризм, - які є плодами зрілого модерну. Позиція екзистенціалістів грунтується на їх баченні інтенційної, безосновної природи свободи, а позиція біхевіористів - на уявленні про шкідливість й антинауковість понять свободи і автономності людини $[12,157]$.

Враховуючи, що «свободо-буття» несе в собі онтологічну тривогу, яку людина намагається угамувати вірою у відсутність вибору, екзистенціалісти протиставляють їй право-необхідність приймати недетермінований вибір, що створює мужню позицію відокремленого індивіда, який обстоює своє право на безосновний вибір. За словами В.В.Ляха, «в період тотального відчуження єдиним захисником автономності індивіда, його свободи, унікальності й неповторності виступив саме екзистенціалізм вкупі з персоналізмом» $[12,168]$.

На думку Б.Ф.Скіннера, автономна свобода, достоїнство людини є ознакою емоційної неврівноваженості та небезпечні для виживання людства. Якщо головним $є$ нормальне гармонійне функціонування соціального організму, то у людини необхідно виробити рефлекс діяти в межах правил, означених суспільством. Заради «виживання культури» контролюючий соціум має маніпулювати людьми через ретельну регламентацію поведінки особи, і тоді соціальні конфлікти індустріального суспільства буде усунуто [12, 169-178].

Наведена концепція спрямовує нашу увагу до теми влади, «легітимного насилля». Проблема влади, iї сили, примусу найяскравіше увиразнюється в полеміці між Ю.Габермасом і М.Фуко. Обидва артикулюють дві протилежні позиції щодо можливості-неможливості існування суспільства, продуктивної соціальності без репресивних засобів, насильства, нагляду. Чи достатньо для існування суспільства соцієтальної спільності як його ядра, сукупності колективів, організованих на основі єдиних норм, цінностей, зразків, що інтегрують суспільство разом із економічною, політичною та іншими системами (Т.Парсонс)? На дану стратегію вказував Р. Дарендорф, підкреслюючи, що наявність соціальних лігатур чи глибоких зв'язків, які є традиційними формами причетності до організованої спільноти, 
уможливлюють вибір і перспективи для громадян, попереджують виникнення аномії і безладдя, хоча водночас можуть і перешкоджати розвитку $[11,14]$. Або ж слід дотримуватися іншої стратегії, коли потрібен «паноптикум», що містить ризик тоталітарної організації буття людей на основі приписів і покорі державній волі під iii суворим постійним наглядом? Така модель $є$ прямим, але спотвореним наслідком прагнення до реалізації утопій, які втілились $\mathrm{i}$ відобразились як антиутопії, класичними прикладами яких так багата історія і література XX ст. (Є.Замятін, О.Гакслі, Дж. Орвел).

Модерну владу можна розглядати не лише як інституалізовану структуру, а як систему впливу на людей, відповідно до викликів часу і уявлень про спільне благо. Так, регулюючий вплив табу переходить у племінну етику, яка змінюється мораллю в складних суспільствах, де людина випадає з традиційної спільноти і має на основі солідарності та відповідальності у власному житті поєднувати вимоги різних груп, до яких вона входить, не втрачаючи своєї ідентичності. Щодо ідентичності, то, на думку В.В.Ляха, іiі історичне становлення проходило через низку криз, пов'язаних із змінами типів суспільства, з переходом від традиційних аграрних первісних ідентичностей (патріархальних, сімейних, релігійних, етнічних) до індустріальних (класу, праці, корпорації, дозвілля, нації). У підсумку даних змін, коли кількість соціальних контактів збільшувалась, а їх якість, інтенсивність зменшувалась, коли зв'язки ставали функціональними, фрагментарними, виникла так звана «модульна особистість», яка перебувала в ситуації певної ізоляції, самотності. Така особистість складається з великої кількості модулів, які, відповідно до вимог ситуації, залучаються або вилучаються і є взаємозамінними $[11,12]$.

Такі вимоги створюють внутрішній конфлікт, подолати який допомагають загальноприйняті конструкти соціальності, що окреслюють нове бачення особистості. Уявлення про індивіда трансформувалися таким чином, що, за висловом Л. Дюмона, він став «квазісвященною, абсолютною істотою», законні вимоги якої є найвищими, а права обмежуються лише правами інших індивідів [10, 141]. Науковий світогляд, ідея зрілості, необхідна для ізольованого «я» громадян, сформулювали нові узвичаєні форми невіри, що вже стали так званим здоровим глуздом. Так, за інтерпретацією модерного матеріалізму, змінюється розуміння атараксії - людина в безцільному Всесвіті має сама визначати свою долю, вирішувати, до чого прагнути. Сенс шукають всередині самої людини, яка має визначати 
устрій людського світу, порядок свободи [14, 575-577], свою працю $[16,17]$ та ін. Антропоцентричний поворот створив ситуацію модерної духовності, коли Божественні цілі замінились ідеєю цінності людського життя. Модерна людина пізнає і усвідомлює, як сказав Б.Рассел, свою космічну самотність, яка лякає і надихає ізольоване «я», що відчуває свою темну генезу, походження 3 дикого долюдського.

Подібне самовідчуття виникає в секуляризованому демократичному суспільстві, в основі якого лежить ідея суверенності, свободи особи і народів, становлення яких відбувається в період звільнення від традицій, від ієрархічності монархічної спадкоємної влади [10, 131]. Цей процес М.Вебер назвав «розчаклуванням», а Ч. Тейлор пішов далі, назвавши домодерний світ «зачаклованим» (світом духів, демонів і моральних сил), а модерний - «розчаклованим». На думку Б. Латура, у вірі у розчаклований новочасний світ міститься проблема релятивізму [9, 191].

Одним із базових конструктів новочасності є «раціональне», що, за М.Вебером, є процесом деміфологізації і вивільнення профанної культури з сакральної картини світу, яка перебувала в процесі розпаду. Зрештою виникають наука, мораль і мистецтво, як відокремлені одна від одної і від соціального спілкування, повсякденного спільного життя частини, коли кожна зі сфер створює свій тип компетентності $[17,31]$.

Дослідженням теми відношення сакрального і профанного у створенні соціальної тканини приділяв увагу Роже Каюа. Сфера профанного, вважав він, - є сферою спільного досвіду, діяльності, безпосередніх справ. Світ сакрального є світом небезпеки і захисту, світом, перед яким людина відчуває свою слабкість і без допомоги якого стає лише наміром, приреченим на крах [8, 39-40]. Свята, містерії, карнавали єднали групу, створювали спільноту. Модерний час змінює їх значення, але не функцію. Роль свят починають виконувати війни, які також відбуваються в сакральному часі й просторі i, позбавлені повсякденності, руйнують нересурсний порядок i $\epsilon$ розплатою за цивілізацію. Містерії замінюються грою, яка також формує соціальну тканину групи, суспільства. Саме гра стимулює творчість, рухає суспільство вперед i, на думку Г. Маркузе, протистоїть духові серйозності - модерному раціоналізму, який запанував у період відчуження та примусової праці. Завершення часу індустріального суспільства викликає до життя теорії, пов'язані із 
самореалізацією особистості: «цивілізація дозвілля» досліджує Ж. Дюмазедьє, «людину граючу» (Homo ludens) - Й. Гейзінга, особистість, яка самоактуалізується, - А. Маслоу та ін.

Секуляризація, «винесення» Бога за дужки, реалізація виключального гуманізму формує і формується новим відчуттям «я» та свого місця в космосі. «Я» перестало бути відкритим, пористим та вразливим для світу духів і сил, а перетворилося на «ізольоване», впевнене у своїх силах щодо морального впорядкування [14, 49-53]. Таким, що має своєрідну оболонку, яка як буфер захищає від впливів зовнішнього світу, а непроникність якої регулюється самим «я» відповідно до контексту і викликів, що було необхідно для атомізованого тогочасного суспільства.

Цивілізаційний процес, історична еволюція відображають особливості трансформації соціальних зв'язків за часів модерну, коли за кілька століть суспільства, створені і скріплені кров'ю й кодексом честі, поступово змінилися суспільствами «поліцейського типу», в яких зменшується кількість повсякденного насильства та його прийнятність (з XVII ст. дуелі стають злочином). Надмірну імпульсивність традиційних суспільств було замінено системою регулювання поведінки людини через іiі самоконтроль. Зусилля держави і ринку відокремили модерне суспільство від традиційного, сприяючи виникненню нової соціальної логіки, пов'язаної зі зменшенням жорстокості, розумінням нового значення міжособистих відносин. Символічна централізація спричинила розрив та знецінення колишніх феодальних зв'язків особистої залежності, появу самостійного індивіда, егоцентричної моделі сприйняття світу [10, 273-277].

Прагнення до утвердження модерного суспільства 3 часом викликало зворотній рух до традиціоналізму. Бажання надмірного виокремлення і доведення до найвищого рівня розвитку як традиційного суспільства, з притаманною йому спільнотністю, так і модерного суспільства, з характерною суспільністю - такі спроби, за влучним узагальненням В.Срмоленка, дісталися логічної точки, що межує із абсурдністю, робить як традиційне, так і модерне суспільство нестерпним для життя $[7,12]$.

Початок формування соціальності як особливого виміру людського буття припадає на період атомізації традиційного суспільства та створення суспільності. В той час було зруйновано властиві спільнотності інтегруючі умови, зникла одинична ідентичність, яка приписувалась від народження, але інтенсивно набувалися нові 
зв’язки, які б утримували буття суспільної тканини. Людина мала вже в процесі життя набути власної ідентичності. Формуються закриті суспільні інститути, суспільна ієрархія, соціальні групи, приналежність до яких вимагала від особистості набуття нових якостей, соціальності, присвоєння нових ідентичностей. Так, людина, яка належала до різних груп та ідентифікувала себе з ними, своїм життям пов'язувала їх у соціальну тканину на базовому практичному рівні, ставала вузлом соціальності. На метарівні таку функцію виконували нова етика, спільні цінності, ідеологія. Спроможність людини до створення нових цінностей, (яку Ф.Ніцше вбачав в образі безпосередньої творчості дитини), базується і водночас формує модерний гуманізм, який «мав віднайти певну заміну агапе» $[14,53]$. Відбувається сакралізація «нової людини», нації, ідеї рівності та прогресу, які окреслюють нове поле соціального буття.

\section{ЛІТЕРАТУРА}

1. Андерсон Б. Уявлені спільноти: міркування щодо походження й поширення націоналізму. - К., 2001. - 272 с.

2. Бауман 3. Плинні часи: життя в добу непевности. - К., 2013. - 176 с.

3. Бауман 3. Свобода. - М., 2006. - 132 с.

4. Баумейстер А. Ідея модерну і традиція Заходу [Електронний ресурс] 2010 Режим доступу до ресурсу:

http://theology.in.ua/ua/bp/theological_source/philosophy/38039/

5. Волковський В.П. Становлення ідеї суспільності у філософській думці України XIX століття : автореф. дис. на здобуття наук. ступеня канд. філос. наук : спец. 09.00.05 «історія філософії». - К., 2015. - 20 с.

6. Гидденс Э. Последствия современности. - М., 2011. - 352 с.

7. Срмоленко В. Оповідач і філософ Вальтер Беньямін та його час. - К., 2011. $-280 \mathrm{c}$.

8. Каюа Р. Людина та сакральне. - К., 2003. - 256 с.

9. Латур Б. Нового Времени не было. Эссе по симметричной антропологии. - СПб., 2006. - 240 с.

10. Липовецки Ж. Эра пустоты: эссе о современном индивидуализме. СПб., 2001. - $336 \mathrm{c.}$

11. Лях В.В. Свобода і пошук нових форм ідентичності в добу глобалізації // Мультиверсум. Філософський альманах. - К., - 2006. - № 57. - С.3-19.

12. Свобода: сучасні виміри та альтернативи. - К., 2004. -486 с.

13. Славой Ж. Дражливий суб'єкт: відсутній центр політичної онтологіï. - К.. $-510 \mathrm{c}$. 
14. Тейлор Ч. Секулярна доба. Книга перша. - К., 2013. - 664 с.

15. Тьонніс $Ф$. Спільнота та суспільство. - К., 2005. - 262 с.

16. Форд Г. Моє життя та робота. - К., 2015. - 384 с.

17. Шамрай B.B. Модерне суспільство: від ліберальної і тотальної утопій до мережної соціальності. - К., 2015. - 306 с.

18. Szanto T., Moran D. Phenomenology of Sociality. Discovering the «We». New York and London: Routledge Taylor \& Francis Group, 2016

Лукашенко М.В. Формування соиіальності як особливого виміру людського буття в модерний час.

В статті розглядається процес формування соціальності, як особливого новочасного виміру буття людини. Фіксуються зміни в сприйнятті таких їі атрибутів, як соціальний час і простір, системи цінностей та пам'яті, зміни в уявленнях про мораль, істину та ії пізнання. Досліджується тема «зачаклованого» i «розчаклованого» світу, сакрального і профанного у створенні соціальної тканини. Соціальність аналізується в контексті уявлених спільнот, спільнот та суспільства, суспільства та колективів (в розумінні Б. Латура). Системи модерної інтеграції суспільства описуються через «нову» особистість із її «свободо-буттям» та владою над нею.

Ключові слова: модерн, соціальність, суспільність, суспільство, спільнота, уявлені спільноти, свобода.

Лукашенко М.В. Формирование социальности как особенного измерения человеческого бытия в модерное время.

В статье рассмотрена социальность как особое нововременное измерение бытия человека. Описываются изменения таких его атрибутов как время, особенности его восприятия и конструирования, системы ценностей, представлений о морали, истине, свободе, познании. Социальность анализируется в контексте дихотомий общинности и общественности, общин и общества, общества и коллективов по Б. Латуру. В ключе модерной интеграции общества социальность развивалась в гражданском политико-идеологическом поле, в поле наций как воображаемых сообществ, носителем которой есть новая личность, наделенная свободо-бытием.

Ключевые слова: модерн, социальность, общественность, общество, община, воображаемые сообщества, свобода.

Lukashenko M.V. The formation of sociality as a special dimension of human existence in the modern time.

The sociality as a special modern dimension of human existence is considered in this article. Such changes of its attributes as time, especially its perception and construction, values, the conception of morality, truth, freedom and cognition are described. Sociality is analyzed in the context of the dichot- 
omies of community and sociability, communities and society, society and collectives (B.Latour). In the vein of modern society integration sociality developed in a civil political-ideological field, in the field of nations as imaginary communities, the bearer of which is a new personality, endowed with a freedom-being.

Key words: modernity, sociality, sociability, society, community, imaginary communities, freedom. 